City University of New York (CUNY)

CUNY Academic Works

2016

\title{
A Case Study of the Progressive Era Librarian Edith Guerrier: The Public Library, Social Reform, 'New Women', and Urban Immigrant Girls
}

Margaret Bausman

CUNY Hunter College

\section{How does access to this work benefit you? Let us know!}

More information about this work at: https://academicworks.cuny.edu/hc_pubs/611

Discover additional works at: https://academicworks.cuny.edu

This work is made publicly available by the City University of New York (CUNY).

Contact: AcademicWorks@cuny.edu 


\title{
A Case Study of the Progressive Era Librarian Edith Guerrier: The Public Library, Social Reform, 'New Women', and Urban Immigrant Girls
}

\author{
MARGARET BAUSMAN \\ Hunter College Libraries, City University of New York, USA
}

This paper investigates the intertwined evolution of librarianship and social welfare work during the Progressive Era (1900-1920) via a case study of the librarian Edith Guerrier (1870-1958). From 1898 through 1917, Guerrier worked in the immigrant community of Boston's North End. She established a programme of girls' reading groups that provided access to core elements of a progressive liberal arts education. The most notable of these was the Saturday Evening Girls (SEG). Concurrently, Guerrier established the Paul Revere Pottery, a retail art pottery studio run by the young women of the SEG. Using Guerrier's varied career as a starting point, this paper explores the role of the 'new woman' as an agent of social change versus social control, progressive library programmes and their promotion of reading material, and issues of acculturation, cultural plurality, and personal agency among immigrant girls and young women.

KEYWORDS Progressive Era, library history, social welfare history, 'new women', immigrants, Edith Guerrier, Saturday Evening Girls, Paul Revere Pottery

\section{Introduction: a transforming America, 1880-1920}

Historians debate whether America's Gilded Age (I880-I900) and Progressive Era (I900-I920) rightly constitute two distinct historical time periods or ought to be considered on a continuum without demarcation; they are generally agreed, however, that the intense political and economic turbulence that permeated the Gilded Age helped to usher in the profound social reordering and social reform ideologies of the Progressive Era. ${ }^{\mathrm{I}}$ The final two decades of the nineteenth century were not only tumultuous but 
also transformational. Technological advances stemming from the refinement of steel, the burgeoning use of electricity, and the invention of the internal combustion engine led to an exponential acceleration in industrialisation. An unprecedented expanse between the wealthiest and the poorest Americans opened up, leaving fewer people in the financially stable middle ground. ${ }^{2}$ The 1890 s were marked by riotous labour disputes, including the Homestead and the Pullman strikes, and unrelenting economic depression. It was a decade in which the democratic process approached oligarchy as powerful elites used their considerable wealth to manipulate the election of government officials as well as the legislative process to the benefit of their business agenda and frequently at the expense of the working and lower classes. ${ }^{3}$

The social repercussions were profound. The United States underwent a demographic redistribution in which the populace shifted from a rural, agrarian lifestyle, arranged socially around close kinship networks, to urban, industrialised centers arranged around mass production and big business with a diffuse supporting social structure. ${ }^{4}$ Concurrently, successive waves of immigration from Ireland, Eastern Europe, Russia, and Italy filled the cities with cheap and easily exploitable labour. The existing physical and social infrastructures were inadequate to support the influx of both international and rural emigration at such a volume, resulting in communities beset by urban blight and replete with rampant overcrowding, poverty, and disease. ${ }^{5}$

The advent of the twentieth century proved to be a watershed decade for the nation, politically, economically, and socially. Simultaneously products of and respondents to the intense socioeconomic churn, the emerging 'helping professions' of librarianship and social work stood on the front line of the Progressive Era reform movement, their dual evolution intrinsically and complexly intertwined. In particular, urban libraries and settlement houses had the capacity to impact vulnerable immigrant populations, potentially setting individuals on a lifelong course while contributing to the social health of an entire community. An instructive example which naturally highlights the amalgamation of ideologies and cross-disciplinary nature of Progressive Era reform-oriented librarianship rests in the case of Edith Guerrier (1870-I958), the Saturday Evening Girls (SEG), and the Paul Revere Pottery (PRP).

Following a brief exposition of the dual evolution of professional librarianship and social welfare work in this period, the paper introduces the figure of Edith Guerrier, detailing and contextualising her leadership of the reading clubs, the SEG, and the PRP. It suggests that the SEG and the PRP were unique hybrids of the public library and social welfare movements, delineating how they merged with as well as deviated from standard functions of Progressive Era youth library services and settlement house ideology. The discussion pivots on the experience of urban, European immigrant women and the overarching response to this population by 'new women' involved in library and social welfare work. The paper considers how the SEG and the PRP served not only as protective factors against the biopsychosocial risks associated with urbanisation but also how they served to promote members' acculturation and personal agency in a culturally pluralistic sense. Last, the discussion will reflect upon Guerrier's identity as a 'new woman' and explore the tension inherent in her role as a proponent of personal agency versus a proxy for social control. 


\section{Transformation: the public library movement}

Through the Gilded Age, the public library movement in the United States gained momentum. Boston, in particular, had been a forerunner thanks largely to the influence of Alexander Vattemare, a French ventriloquist who lobbied for an international system for the free exchange of books. His efforts in the United States were instrumental in the establishment of the Boston Public Library in 1848 , the first such institution in a major metropolis. ${ }^{6}$ Founded in 1876 , the American Library Association struggled through the Gilded Age to define the role, function, structure, and mission of the public library. The bedrock of the profession purportedly lay in the provision of access to information for the entire populace through a free, democratic, egalitarian, publicly supported institution. But what exactly this meant and how best to achieve it generated decades of fierce debate and an intense evolutionary process. ${ }^{7}$

During the Gilded Age, librarians debated whether the library should be seen as a vehicle for cultural uplift or simply a neutral provider of leisure activity, considering the balance between the two functions and the resulting impact on library services and spaces. ${ }^{8}$ Many deemed the urban public library as uniquely poised to grapple with the socioeconomic instability of marginalised communities, such as those of the lower classes and immigrants, and perfectly positioned to fill educational and acculturation gaps. They asserted that the poor and immigrants could achieve self-sufficiency through exposure not only to library resources but also through programmes and materials which reinforced Victorian, middle-class American values and concepts of patriotism. Others advocated for the library's ability to provide recreation and leisure activity as an alternative to the vice encountered in barrooms, dance halls, and other less than reputable venues. ${ }^{9}$

Garrison describes early library leaders as 'genteel' and 'elite'. She notes that a preponderance of Gilded Age library leaders had also trained as clergy and that their library endeavours were very much mission-driven. These leaders sought to uplift the poor by providing examples of social morality and ethical guidance: Not only should the library combat moral ignorance but, by doing so, it could restore social order. These early leaders espoused education as the solution to the destabilising consequences of industrialisation and immigration, but only to the degree that the 'right' books and the moral example of the 'library hostess' would inculcate into the poor and lower classes a proper Victorian social ethos. ${ }^{\text {IO }}$

As the ideological shifts of the Progressive Era reform movement gained traction, librarians began to step outside the role of the morally upright hostess to that of active contributor to the mechanisms of social reform. Library services began to reflect this shift in several distinct ways. Libraries began to take on community-oriented, social service functions. Branch libraries developed a community-centre structure by providing meeting spaces, kitchens, and bathrooms and by extending hours of operation to include evenings and weekends. Library systems established 'delivery stations' embedded into other community settings, including settlement houses and tenements, through which library materials were circulated. Librarians organised non-book-related activities such as presentations, lectures, contests, and ongoing community groups for both education and leisure. And, finally, libraries began to develop services and programmes focusing on the specific reading and leisure needs of children and adolescents. ${ }^{\text {II }}$ 
Many of these active librarians represented a new type of young middle-class woman who sought an alternative to the confines of a Victorian marriage in which gender roles were firmly established, centring women on home and family exclusively. Indeed, as increasing numbers of women completed a college education, they sought opportunities to enter vocational settings in which their intellectual pursuits might flourish. A sociological construct singular to the time period, such women, many of whom eschewed marriage and family for service and career, were called 'new women'. ${ }^{\text {I2 }}$ Such a role was sanctioned for women who were in need of an income and when it was performed under male supervision. Further, the low pay scale of a female workforce represented an economic efficiency in a tenuously funded, evolving profession, the value of which was still undetermined. ${ }^{\mathrm{I} 3}$ Thereby, 'new women' were instrumental in shaping the underpinnings of the public library system. ${ }^{\mathrm{I}}{ }^{\mathrm{T}}$

\section{Transformation: the social welfare movement}

Deeply intertwined with this, the evolution of the social welfare movement followed a parallel trajectory both ideologically and in the gendering of its workforce. By the I88os, social welfare efforts were dominated by the Charity Organization Society (COS) movement. Typically governing a specific geographic area, a COS was essentially a consortium of private organisations with the shared mission of redressing the circumstances of the destitute. The COS functioned as a clearinghouse with the goal of ensuring a fair distribution of resources to the 'right' recipients. ${ }^{\text {I5 }}$

The COS's ideology stemmed largely from three powerful business, social, and religious tenets of the Gilded Era. The first championed 'natural' law, or the right of supply and demand and unregulated capitalism. This was known as the 'steel chain of ideas'. The second, Social Darwinism, applied the theoretical foundation of 'survival of the fittest' to the social arena. And last, the 'Gospel of Wealth' viewed financial wellbeing as a reward from God for hard work and conversely ascribed a state of poverty to personal slothfulness. ${ }^{\text {I6 }}$

The COS understood social problems, such as poverty, to be individual moral failings. It espoused the idea that providing outright support to the poor would create dependency and lead to the creation of a permanent underclass. The COS deemed it preferable that those who were not able to function according to a Victorian middleclass standard should naturally dwindle out of the populace. ${ }^{17}$

The aid that the COS movement provided was reactionary, designed as a last resort for the 'deserving' poor. Widows, families headed by disabled husbands, and victims of fires might fall under the 'deserving' umbrella, while those confronted by persistent poverty, poor education, addiction, or mental illness would not. Akin to the 'library hostess', the 'friendly visitor' was a volunteer, usually a woman, who would visit the 'deserving' family on a regular basis in order to provide limited concrete support, domestic education, and moral instruction but above all to set an example. It was thought that a model to emulate would elevate the recipient's moral centre, which would in turn ultimately lead to behaviour or consequences which would remediate need. $^{\text {I8 }}$

Just as the Progressive Era library shifted in philosophy and practice, reaction to the COS movement arose through urban social welfare workers, who sought to replicate 
the British Settlement House movement, most notably London's Toynbee Hall. The American Settlement House movement espoused a democratic and fraternal philosophy. ${ }^{\text {I9 }}$ Its ideology was tied to a vocational reordering of an evolving middle class, as seen in the emergence of the social sciences, which included the fields of economics, psychology, sociology, and political science and emphasised the practice of empirical, inductive methods. The development of distinct arenas of professional expertise included not only medicine, the law, engineering, and journalism but also the 'feminized', 'helping' professions of nursing, teaching, social work, and librarianship. Concurrently, the social gospel movement captivated many such young professionals through its operationalisation of faith as a commitment to ethical behaviour, active service to community, and the promotion of social justice. ${ }^{20}$

The Settlement House movement reframed social problems, such as poverty, as a form of oppression, not a moral failing. Therefore, social justice was the solution. The ideology went on to suggest that social reform must occur in the public sector, not through private organisations. And finally, the Settlement House movement asserted that it was through collaboration that one could identify need. Therefore, those who sought to make change must reside in and function as part of the community they sought to assist. ${ }^{2 \mathrm{I}}$

Accordingly, settlement houses were established in targeted communities, primarily immigrant ones, with three overarching aims: (I) to work within the context of the community, (2) to include everyone in the community proactively rather than a select few reactively, and (3) to acknowledge that the health and functioning of the community was of equal importance to that of the individual. The Settlement House movement practised the 'Three R Doctrine': Residence, Research, and Reform. ${ }^{22}$

The Settlement House personnel consisted largely of middle- to upper-class collegeeducated young people. Nascent social scientists, writers, and service professionals often found their niche in settlement houses. Just as 'new women' took on an interventionist role in libraries, so too 'new women' took central leadership roles in social reform, championing causes such as suffrage, women's and children's rights, labour unionisation, free press, and pacifism. ${ }^{23}$

\section{Edith Guerrier (1870-1958)}

Guerrier's family history and biography are richly multifaceted and well worthy of scholarship beyond the scope of this paper. Guerrier was maternally bereaved at the age of three, and her early childhood was marked by disrupted custodial care as she was shuttled between different branches of her parents' families. Guerrier referred to the periods of upbringing by her mother's family, the Ricketsons, as 'com[ing] back to my own people'. ${ }^{24}$ Well-to-do abolitionists, naturalists, and transcendentalists, the Ricketsons cultivated robust friendships with many of the like-minded intellectual elite of the time including Henry David Thoreau, the Alcott family, and Ralph Waldo Emerson. ${ }^{25}$ This proved to be a formative influence on Guerrier's adult and professional life.

Guerrier arrived in Boston in I89I, at which time Boston's North End represented one of the most densely populated urban immigrant enclaves in history. ${ }^{26}$ She did not arrive with ambitions towards either librarianship or social reform. At the age of 
twenty-one, although she displayed only modest talent, Guerrier aspired to be an artist. Through the sale of family property, Guerrier's father provided funds for her to attend the school of the Boston Museum of Fine Arts. Unfortunately, or fortunately as it turned out, these funds proved insufficient to enable Guerrier to maintain a full-time student status during the economically turbulent I890s, and so she sought a position in the nursery of the North Bennett Street Industrial School, which was run by the wellknown philanthropist and educator Pauline Agassiz Shaw. ${ }^{27}$

At this time, the mission and the services of North Bennett Street underwent enormous shifts replicating those rippling across the social welfare landscape. Originally developed in the early I880s through the COS in Boston, North Bennett Street was initially focused on providing vocational training for widows and the wives of incapacitated husbands. However, over the years and under Mrs Shaw's guidance, North Bennett Street morphed into an institution which increasingly took on the principles and functions of the Settlement House movement. ${ }^{28}$

Guerrier's natural aptitude for engaging with the children and women of the nursery programme was quickly evidenced. She moved on to become the custodian for the North Bennett Street delivery station of the Boston Public Library and the coordinator of its reading room. During these early years of her tenure, North Bennett Street steadily developed community-based programmes aimed at overcoming social obstacles for the immigrant community, in keeping with the Settlement House ideology. However, the children's and youth programmes almost exclusively targeted boys. Those targeting girls tended to be domestically oriented and geared towards the reinforcement of gender-based role expectations. ${ }^{29}$

By I899, Guerrier had created a series of girls' reading clubs that met in the afternoons and evenings. The oldest girls met on Saturday evenings and named themselves the 'Saturday Evening Girls' or the SEG. The SEG began simply, being conceptualised as a 'story hour'. The initial meetings consisted of four thirty-minute quarters: a business meeting, storytelling, singing, and dancing or games. Over time, Guerrier developed other groups which were each named for the day of the week and time of day of their meeting, each targeting a different age group, starting with fourth graders. Observing that the intellectual capacities and development of young immigrant women were essentially overlooked, Guerrier shaped these groups so as to provide this disenfranchised cohort with exposure to the core elements one would have encountered in a progressive liberal arts education. ${ }^{30}$

The SEG studied classic as well as current literature, social philosophy, and political discourse. They studied music and dance, including those forms culturally connected to the group's membership. Calling on her social and familial connections, Guerrier recruited speakers from the Boston intellectual elite, bringing the club's constituency into personal contact with prominent theologians, politicians, writers, and social reformers of the time. In order that they might have the opportunity to engage with the American political process, Guerrier infused the functioning of the SEG with a self-governing, democratic framework. From I9I3 to I9I7, the SEG published a serial newsletter entitled The SEG News. The SEG News reported on the activities of the club and news of its membership and printed reviews of events of interest, informational pieces about individuals and organisations within the North End Community, editorials, and original prose. ${ }^{3 \mathrm{I}}$ 
The reading clubs' membership included primarily the daughters of Jewish, Eastern European, and southern Italian immigrants, which is noteworthy for several reasons. First, even in the overcrowded confines of Boston's North End, differing ethnic groups tended to function in segregated fashion. These invisible boundaries existed on various lines including nationality, creed, language, trade, and politics. For some girls, Guerrier's reading clubs were the first experience of mixing with others outside their own ethnic enclave in an ongoing, relational format. Second, within immigrant families there was often intergenerational discord surrounding activities and influences that were perceived to promote assimilation. To some immigrant families, a daughter's participation in such clubs presented the risk of 'losing' their child to the dominant culture. Larson notes that many SEG members hid or understated their participation so as to allay parental resistance. ${ }^{32}$

By I9I5, there were over 250 girls enrolled in Guerrier's reading clubs. ${ }^{33}$ Guerrier was increasingly aware that intellectual enrichment in and of itself was not a solution to the economic needs of the SEG membership or their families. ${ }^{34}$ Indeed, most children of this community joined the workforce following completion of a primary education around the age of fourteen, leaving little time or energy for intellectual pursuits. ${ }^{35}$ Guerrier was joined in this concern by two essential allies, Edith Brown and Helen Osborne Storrow.

During the early I890s, Guerrier participated in free art courses in the evenings, where she met Brown, a talented painter from Nova Scotia. The two soon entered into a committed relationship, established a home together, and began a life partnership which would span forty years until Brown's death in $1932 .{ }^{36}$ Storrow was not part of the 'new woman' demographic as she was neither middle-class nor a member of a 'helping' profession. She was a member of Boston's financial elite whose family had a long history of social activism, and she engaged in what might be described as professional philanthropy. Affiliated with a number of Boston's charitable organisations, Storrow served on the board of the North Bennett Street Industrial School as well as that of the Boston Public Library, among others. ${ }^{37}$

Storrow was most impressed by the North Bennett Street reading clubs, becoming an avid supporter of the SEG and a close personal friend of Guerrier and Brown. She financed a summer camp for the SEG, for example, providing the members with respite out of the city each summer in a simple, bucolic ocean-side retreat. And so it was, in I906, that she sent Guerrier and Brown on a respite of their own, a summer holiday in Europe. It was on a Swiss hiking excursion that they were inspired by a tour of a pottery on Lake Thun. They resolved to create their own pottery with and for the SEG. ${ }^{38}$ Upon their return to Boston, and with Storrow's financial support, Guerrier, Brown, and the SEG learned the pottery craft. In 1908, Storrow purchased a house on Hull Street, around the corner from the North Bennett Street School and under the steeple of the Old North Church to which Paul Revere famously looked for his lantern-lit directives. The ground and first floors were renovated into a working art pottery production studio and retail store. The remainder of the house was subdivided into several selfcontained units. The reading clubs' programme was officially moved to Hull Street, which was dedicated as the Library Club House. Guerrier and Brown rented out their home in Chestnut Hill and took up residence on the top floor of the Hull Street house. Thus, the Paul Revere Pottery (PRP) was born. ${ }^{39}$ 
From I908 through 19I5, many of the young women from the SEG worked in the PRP on Hull Street. They produced high-quality art pottery vases, tableware, and tiles in the Arts and Crafts style popular at that time. Some SEG members earned their library or camp dues by completing routine chores for both the pottery and the Library Club. Others assiduously learned the skills to work full-time as potters and decorators. Still others demonstrated outstanding talents and truly earned distinction in their own right as artisans of the craft. The PRP employees worked five and a half days a week in a clean, sunny studio frequently adorned with flowers while volunteers supplemented the pastoral environment by reading aloud or providing instrumental music. They were remunerated with a living wage and received lunch daily and two weeks' paid vacation per year. ${ }^{40}$

Brown, having completed a degree from the School of the Boston Museum of Fine Arts, became director of the pottery. She studied, learned, and taught, continuously refining her techniques and use of materials to achieve an increasingly distinctive and marketable commodity. She and Guerrier astutely tapped into marketing strategies which included placing Paul Revere Pottery on exhibit. The related print advertisements brought attention to the pottery, the artists, and the wares. They achieved national recognition through review and advertisement in art magazines, ultimately achieving the sale of Paul Revere Pottery in the national department store market. ${ }^{4 \mathrm{I}}$

By I9I4, the PRP had opened a retail store in Back Bay, Boston, a desirable address in the middle- and upper-class shopping community. By I9I5, the PRP outgrew the Hull Street location and relocated to a larger studio in Nottingham Hill in Brighton, while the reading clubs were established at the new Boston Public Library branch on North Bennett Street under Guerrier's continued tutelage. In I9I7, as the United States entered the First World War, a retail venture in Washington was attempted, but the advent of the war began a shift in the market away from Art and Crafts commodities. Having achieved its zenith, the PRP continued to operate from its Nottingham Hill location until its closure in $1942 .{ }^{42}$

\section{Discussion}

If one set out to replicate Guerrier's programmes in the public library or social service arena today, one would be faced with a mountain of grant applications, expense accountings, and reports to 'the Board'. The process would demand strategic and market planning, identification of goals, predictors and definitions of success, the use of evidence-based practices, time lines for review, and the oversight of accreditation authorities. No such formal documentation exists for the reading clubs, the SEG, or PRP. So how closely did these programmes follow the mission and goals of the progressive library and Settlement House movements? How did they deviate? And to what end? How do we understand the impact of the reading clubs, the SEG, and the PRP upon the lives of the young women they served? And how does Guerrier herself expand our understanding of the lives of 'new women', their call to service, and their impact on the social environment?

In their programmes, the reading clubs and the SEG followed the precepts of the three emerging elements of a socially responsive Progressive Era library enumerated previously: (I) the North Bennett Street Industrial School and subsequent Library Club 
House facilities accommodated a range of community needs as well as serving as a delivery station for the Boston Public Library; (2) the SEG engaged in non-book-related activities; and (3) the programmes were child- and youth-specific.

Guerrier's autobiography was discovered in archival holdings in the late I980s, and half of it was published in I992. In this memoir, Guerrier described herself as a librarian but reflected upon her initial trepidation in taking on that mantle. Guerrier perceived the task of guiding young minds to intellectual and moral learning as a great responsibility. While desirous of directing young women to quality materials, Guerrier struggled with the assumption that she should judge what these might be. This hesitancy seems linked to ambivalence around becoming an agent of social control, and indeed, she explicitly renounced efforts not only to control the reading choices of young people but also to dictate morality and behaviour. Guerrier wrote that ultimately she trusted that her young charges would be able to sort the grain from the chaff as she had done herself during her own youth when she read all manner of fiction, emerging from the experience unscathed. ${ }^{43}$

That said, however, Guerrier most certainly did choose reading material for the clubs and influenced SEG programme activities. An issue of The SEG News appearing on 8 May I9I 5 contains the curriculum for the reading clubs for the fourth through twelfth grades. What started as a story hour fifteen years earlier had developed into a cohesive, cumulative course of study according to the topical outline shown in Table I.

How the reading clubs' curriculum was determined is not clear. In her exploration on the history of children as readers, McDowell notes that Progressive Era children's librarians routinely sought to understand the reading habits of their patrons through the use of survey methods. ${ }^{44}$ While Guerrier was quite in tune with her charges, the degree to which their reading preferences were considered is not known, and there is no historical evidence suggesting a methodical survey of the reading clubs' members. Even if there existed archival survey records, McDowell cautions that their analysis would need to be considered in the context of the potential impact of the power differential between a child patron and an adult surveyor. Further, McDowell notes that Progressive Era children's librarians developed recommended books lists both for home and

TABLE 1

EXAMPLES FROM THE SEG READING CLUB'S CURRICULUM

\begin{tabular}{|c|c|c|}
\hline Grade & Subject & Examples \\
\hline Fourth grade & Folktales & Thumbelina, Red Shoes, Faithful John \\
\hline Fifth grade & Myths, legends, and history & Midas, Moses, Columbus \\
\hline Sixth grade & Favourite stories & Christmas Carol, Heidi, Secret Garden \\
\hline Fourth-sixth grades & Poems & Tennyson, Longfellow, Milton \\
\hline Seventh grade & History stories & Magellan, Boston Tea Party, Lincoln \\
\hline Eighth grade & Classics & Iliad, Siegfried, Faust, Undine \\
\hline First year high & Novels & Kidnapped, Silas Marner, Les Misérables \\
\hline Second year high & Authors & Chaucer, Shakespeare, Burns, Austen \\
\hline Third year high & Travel around the world & Paris, the Rhine, Genoa, Gibraltar \\
\hline Fourth year high & Music & Bach, Rossini, Mendelssohn, Rubinstein \\
\hline \multicolumn{2}{|c|}{ List of ethical subjects for all grades } & Order, perseverance, friendship, honesty \\
\hline
\end{tabular}

Source: SEG News, 3.7 (8 May I9I5). 
library collections, which certainly may have influenced the selection of material for Guerrier's reading groups. Chief among these was Caroline Hewins's Books for Boys and Girls published in I897, I904, and I9I $5 .{ }^{45}$

Perhaps most revealing in the evaluation of Guerrier's curriculum against Hewins's I9I5 list are not the many commonalities but the subject areas absent from the clubs' curriculum that are covered by Hewins: amusements and handicrafts, cooking, housework and sewing, dolls, gardening, and magic. ${ }^{46}$ One may infer that in her selection, Guerrier opted for classic and intellectually stimulating material over material aligned to reinforce gender role and socially sanctioned gendered interests.

Concurrently, the SEG encouraged individual assessment of reading material. The I2 February I9I6 edition offers an article by Elizabeth M. Richardson of Boston's Girls' High School entitled 'Good Books and Bad'. While intended as a guide for evaluating the value of a book, it is not prescriptive. Instead it offers SEG readers a thoughtful process by which they might apply their own critical thinking to the content, intent, and form of the story. Richardson wrote:

Our satisfaction in a story, our sense that it is 'good', must, then, come from our conviction that the causes presented in the tale would inevitably bring about the results shown; from the assurance that the author has so truly mirrored human life with its logical outcome that we may say, 'Yes, under such circumstances, all should act in this way, avoid that way of life.' The writer has then universalized his reading, acted the part of prophet to his age. ${ }^{47}$

Likewise, the SEG's activities covered a broad-minded programme, exposing the participants to classic and current literature, social philosophy, and political discourse as well as encouraging attendance at cultural events and venues and participation in sociopolitical affairs. The SEG News published reviews of SEG members' attendance at political, cultural, and social events, reports of social welfare organisations throughout Boston, and articles guest-written by academics and professionals from all over the Boston area. For example, on Io April I9I5 the SEG News contained the following offerings: 'The Power of Endless Life' by Rev. Paul Revere Frothingham, 'Passover: An Interpretation' by James Marcus, 'The Work of a District Doctor' by Harry Olin, MD, 'The Swineheard: A Play for Children' by Edith Guerrier, and articles on school gardening, Chinese music, the evolution of ballet, the future of immigration, library news, North End news items, and a book review. ${ }^{48}$

We must be somewhat less definitive on the question of whether the PRP was a settlement house per se, although it met many of the core ideological components previously discussed. First and foremost, the Hull Street pottery existed in the context of the community, and the leadership resided there. Second, the pottery offered a proactive approach and not a service of last resort. And last, the pottery's establishment in the North End acknowledged that a stable business enhanced the health of the whole community. However, employment opportunities at the pottery were limited to the SEG membership. Further, the pottery did not seek to reform an existing public system or create a new public service to remediate a need. It was never self-sustaining, and it was through Storrow's perpetual financial support and the fundraising efforts of the SEG that the PRP provided a privately subsidised opportunity for a select few. ${ }^{49}$ These are significant deviations from the Settlement House ideology. 
It is perhaps more useful to view the PRP as a hybrid of the Settlement House and Arts and Crafts movements. While a full exploration is beyond the scale of this paper, the PRP adhered to many central tenets of the Arts and Crafts movement pertaining to healthy work spaces, a living remuneration for the artisans, and the commercial promotion of household items that were both functional and beautiful. ${ }^{5 \circ}$

\section{Risks for urban immigrant women}

The immigrant women of urban enclaves such as Boston's North End, and their American-born daughters, faced a daunting socioeconomic landscape with very real risks on multiple fronts. One can only imagine the degree to which the SEG and the PRP offered a reprieve from the present and a possible alternative to an otherwise austere future. Perhaps the most revealing way of exploring such singular aspects of the SEG and the $\mathrm{PRP}$ is in contrast to the boundaries within which urban immigrant women of the time functioned.

Typically entering the workforce in their early adolescence, working-class immigrant girls and women provided a cheap, plentiful source of labour throughout the I89os and into the twentieth century. The impact of industrialisation and urbanisation with regard to the exploitation of women in manufacturing is well known. Working-class women risked their health, literally both life and limb, on a daily basis. Moreover, the entry of women into the workplace, in either a working-class or professional capacity, challenged accepted Victorian gender norms which designated the home as the 'woman's sphere' and the preservation of the family's moral and physical well-being as 'woman's work'. ${ }^{\text {I }}$ Thus, there arose a cultural anxiety that working and/or educated women eroded the moral fabric of the family. There was concern especially that factory work and lower-class leisure activities, such as visiting dance halls, exposed young women to influences which would lead them to a 'wayward' lifestyle. ${ }^{52}$

A factor supporting this social anxiety was promoted by the psychologist G. Stanley Hall's postulation of adolescence as a distinct developmental stage. This is now a wellaccepted precept of developmental theory, but at the time it was based on the assumption that adolescent girls were innately fragile. Hall maintained that both education and work had the capacity to lead young women away from marriage and motherhood towards a 'wayward' lifestyle which included promiscuity, delinquency, and criminality. ${ }^{53}$

As early as the 1850 , the Boston Public Library system was a forerunner in commitment to at-risk youth. Efforts to deter youth from vice focused on social programmes and collection development. ${ }^{54}$ Pierce notes that the cultural concern with the downfall of young women in particular presented the public library movement with a conundrum. The popular press and publishing industries, reflecting the cultural climate, produced enormous quantities of literature concerning working women, the 'new woman', 'wayward' and 'fallen' girls, and delinquency. These topics cut across genre and point of view from warning, censure, prevention, and remediation to sensationalised, romantic, and inflated coverage. Libraries disputed how to manage this: was collection development in the public library to be egalitarian, patron-driven, and comprehensive or was it to be 'controlled' in order to provide a sanitised collection promoting middleclass, Victorian values? 55 
Many in the library movement, those whom Garrison might describe as 'genteel', asserted that it was the library's responsibility to harness the overflow of literature in such ways as to expose young women to carefully selected collections that were designed to encourage morality and were devoid of material which might glamorise or otherwise elevate vice. Hall was a leading advocate of restricted youth collections, and, along with the librarian Lutie Stern, stridently argued that libraries should take a central role in guiding adolescent girls to the 'right kind of book'. ${ }^{6}$ For example, Hamilton-Honey reports on vigorous debates through the early twentieth century as to the morality of serialised fiction for girls. While such series were wildly popular, many libraries opted not to acquire them, as 'with their promotion of education, sports, travel, ecumenicalism, and above all, consumerism for girls, they upset long-standing assumptions about girls' place in community and the family'. ${ }^{57}$

Guerrier's selection of the reading clubs' curriculum ran against that of Hall and Stern. As noted above, she did not endorse a curriculum or collection intended to sway girls towards domesticity or to inoculate them against intellectual pursuits. On the contrary, Guerrier actively promoted material and activities which encouraged educational advancement and intellectual stimulation. There is however, a subtle dialectic at play. Guerrier acknowledged that the SEG membership would likely read all manner of literature, as she had done herself. She conjectured that it was unlikely that reading alone would cause irreparable harm. ${ }^{58}$ And it is reasonable to extrapolate that material deemed less desirable included serial fiction. Yet this did not mean that the SEG curriculum would endorse serial fiction. Indeed, there was no serial fiction in the SEG curriculum, and the Boston Public Library on at least one occasion, in a report to its trustees, decried the appropriateness of the content of products created by the largest supplier of such fiction, the Stratemeyer Syndicate. ${ }^{59}$

In the social welfare arena, reformers were astutley aware of the deleterious impact of poverty and community instability upon children and youth. Their efforts included advocacy for a juvenile court system which acknowledged the unique legal needs of an adolescent to include protective, evaluative, and rehabilitative elements. ${ }^{60}$ The core ideology behind a rehabilitative juvenile justice system is apt and continues today. But its application to the 'problem girl' during the Progressive Era was indeed problematic itself. However well intended, the emerging policies identified 'wayward girls' almost exclusively in the urban immigrant communities. Nearly always, the charges were of a 'moral' nature, meaning that there was a suggestion, perception, or assumption of sexual behaviour. Such a charge could result in the removal of a young women from her community to a reformatory. Routinely, young women were retained in such settings until they reached maturity at the age of twenty-one in order that they might receive treatment and training geared towards reorienting them to a domestic role. Vocational and intellectual ambitions were not encouraged. ${ }^{6 r}$

Further, this cultural anxiety around 'degenerate girls' added to the rationale supporting the cultural purity, social hygiene, and eugenics movements of which many social reformers were proponents. Using scientific methodology, these movements sought to reduce and eliminate undesirable traits in the population by limiting the fertility of those deemed to carry an inferior genetic makeup. ${ }^{62}$ These included those identified as mentally ill, substance-abusing, mentally retarded or 'feeble minded', persistently povertystricken, criminal, and delinquent. Again, the immigrant communities were targeted as 
possessing these traits at far higher rates than were their middle-class counterparts. ${ }^{63}$ Thus, in addition to detention, young immigrant women who became involved with the juvenile justice system were also at high risk of forced sterilisation. ${ }^{64}$

Abrams explores the seeming contradiction in which those who were themselves criticised for eschewing gender role conventions concurrently advocated at a national level for policies designed to control other women. She posits that early social workers actually espoused quite traditional Victorian values as applied to the morality and chastity of immigrant and working-class women. ${ }^{65}$ Through varying historical lenses, Abrams and Curran note the impact of 'maternalism' on the social work profession as a causal factor in this incongruity. ${ }^{66}$ Kennedy notes that with regard to social hygiene, the COS and settlement house factions of the social welfare movement were in accord. ${ }^{67}$

Garrison and Pierce make similar queries of the librarians of the Progressive Era, who as a group largely represented the persona of the 'new woman'. The values of intellectual advancement and enrichment seem antithetical to the forms of censorship and social control that some of these same women promoted in their libraries. Like Abrams, Garrison postulates a reframing : the 'new woman' did not abandon socially conservative Victorian values, but rather than functioning as a Victorian wife who orchestrated the morality of her home and family, she orchestrated instead the morality of her community. ${ }^{68}$

It must be noted, however, that Garrison's assertion as put forth in Apostles of Culture remains contentious. Following its initial publication in 1979, Hildenbrand (in I983), along with others in the feminist community, abjured Garrison's thesis as revisionist. ${ }^{69}$ More recently, this has been echoed by Valentine, who further asserts the argument is useful only in the context of an urban setting. ${ }^{\circ}$ However, while acknowledging the dispute in her 2003 foreword to the reissue of Garrison's book, Pawley noted that to date no one else had offered as cohesive a narrative concerning library history specfically as it pertains to issues of gender and social control. ${ }^{7 \mathrm{I}}$

\section{The SEG and the PRP: protective factors}

It is difficult to assess the degree to which the reading clubs, the SEG, and the PRP served as protective factors against the real risks faced by young immigrant women. Of the hundreds, perhaps thousands, of girls who engaged somewhere on the spectrum of the reading clubs from I899 to I9I7, most surely went on to work in the exploitative, dangerous employment settings of the day. Given the demographic composition of the clubs' membership, certainly some participants ran afoul of the juvenile justice system, experiencing incarceration and the risk of forced sterilisation at rates higher than their peers in the dominant culture, but at what rate in comparison to their peers who did not attend the reading clubs we cannot know.

What we do know specifically about the SEG, however, is remarkable. As individuals, the membership of the SEG went on to continue their education and to achieve an improvement in class status at higher rates than their peers both in the impoverished North End and among the more affluent middle classes. Many SEG members entered professional careers as librarians, social workers, teachers, nurses, and artists. Their children, likewise, statistically surpassed their peers in educational pursuits. ${ }^{72}$ 
Moreover, SEG members maintained their connections to one another for over sixty years. While the full range of the weekly reading groups eventually declined, SEG members maintained contact regularly, not voting to officially disband until I969. Over the years several reunions were arranged, the most notable of which was convened in celebration of Guerrier's eightieth birthday in 1950, and Guerrier published an SEG News supplement entitled the 'Cherry Tree Edition' in $1954 .^{73} \mathrm{In}$ aggregate, this is exceptionally strong anecdotal evidence for both the early public library and the Settlement House movement's capacity to promote positive, enduring change in the human environment.

\section{The SEG: acculturation, cultural pluralism, and agency}

Rather than considering the impact of the SEG through the absence of negative consequences, one might instead pursue more closely its observable impact upon the acculturation of its members. As institutions predicated on community engagement, libraries and settlement houses were among the primary points of contact with immigrant communities during the Free Immigration Era (I876-I924). As such, they were among the first to act as interventionists concerning questions of the immigrants' assimilation into the dominant Anglo-oriented, Victorian culture.

Paul defines assimilation as 'a process of melding where new arrivals acquire the values, outlook, and behavior of the receiving society and over time become incorporated into that society's common cultural life' ${ }^{74}$ Over the last century or so, several prominent theories which describe the process of assimilation are noteworthy. The Chicago School posits a process-oriented theory. ${ }^{75}$ Described by Robert Parks in the I920s, process theory consists of four phases: contact, competition, accommodation, and assimilation. These phases were conceptualised as linear and universal and the outcome as irreversible. $^{76}$

Subsequently, Milton Parks put forth an expanded and more malleable concept. Parks suggested a seven-phase process which was neither linear nor sequential. He submitted that individuals and communities may not achieve full assimilation and may stall at any of the phases. Parks also held that the phases were not weighted equally but that two, cultural and structural assimilation, were key. ${ }^{77}$ Cultural assimilation, also referred to as acculturation, 'involved picking up the language, social mores, and outlook of mainstream society'. ${ }^{78}$ Structural assimilation occurs when the subordinate group integrates into the dominant group's institutions. Parks's theory posits that structural assimilation is the hallmark of completed assimilation, in that for such integration to occur, one must also have completed each of the other six phases of assimilation. ${ }^{79}$

In conjunction with theories concerning the process of assimilation are theories about its optimal outcome. Shaped by myriad socioeconomic-political factors, ideology concerning outcome shifts over time and reciprocally influences policy, practice, and legislation. Through the mid- to late nineteenth century, Anglo-conformity was the goal. Towards the end of the ninteenth century and into the early-twentieth century, a 'melting pot' concept envisioned the merging of immigrants with the dominant culture into a larger homogeneous whole. ${ }^{8 \circ}$ While the latter offered some acknowledgement of the potential contributions of immigrant communities to the greater whole, both 
outcomes are primarily predicated upon the rationale that ethnic traits and values are a liability to the greater community and ought to be purged from the mainstream. ${ }^{8 \mathrm{I}}$

The sociological vehicle associated with both schools of thought was known as Americanization, a cultural phenomenon separate from the legal process of naturalisation. Americanization was a conservative orientation promoted during the Free Immigration Era by Nativists and other groups seeking to restrict immigration. ${ }^{82}$ Activities supporting Americanization emphasised rapid assimilation into the dominant culture through acquisition of the English language and education in American civics. ${ }^{83}$

Early progressives who eschewed Anglo-conformity, the 'melting pot', and Americanization found themselves thwarted in their advocacy by a lack of clarity as to what an alternative position looked like and what its mechanisms and its benefits to the community were. ${ }^{84}$ It was not until I9I5, when Horace Kallen coined the phrase 'cultural pluralism', that an articulated progressive platform began to solidify. Kallen derided the goal of Americanization as coercive, undemocratic, and unconstitutional. ${ }^{85}$

Haas defines cultural pluralism as the '[c] oncept that individual ethnic groups have a right to exist on their own terms within the larger society while retaining their unique cultural heritages'. ${ }^{86}$ Kallen contended that insistence on assimilation promoted inequity and social injustices while cultural pluralism strengthened America. Kallen offered the metaphor of 'the symphony of civilizations' to illustrate his vision: The coalescence of vast differences and the orchestration of unique contributions create a whole far more stimulating and enriching than any one part alone. ${ }^{87}$

Plummer Alston Jones Jr, a preeminent scholar on the history of the libraries' interaction with immigrant communities, explores the evolution of library services to immigrants during the Free Immigration Era. In addition to noting the Nativist predilection for identifying a causal relationship between immigration and violent labour disputes and economic depression, Jones adroitly draws out underlying aspects of racism inherent to Americanization efforts. ${ }^{88}$

Prior to the mid-I870s, immigration flowed primarily from northern Europe and the United Kingdom, in contrast to the subsequent influx of immigrants from Eastern and southern Europe, which included those of Jewish origins and darker complexions who were perceived as more obviously 'other'. There was concern that those from this new immigrant cohort would not be assimilated into the dominant culture with the same alacrity as had their predecessors. Moreover, those identified as welcomed for Americanization, or for that matter in keeping with the tenets of cultural pluralism, did not include those of Asian, African, or Native American descent. ${ }^{89}$

Jones observes that the progressive library as an institution assumed an apolitical stance in which immigration was an existing social condition to which it had an obligation to respond. He notes that 'On the whole, Librarians as a profession viewed immigrants as Americans in the making [...] Librarians demonstrated a progressive laissezfaire attitude toward immigrants, including not only a tolerance for but an appreciation of cultural differences'. Jones asserts that the library's sole goal with regard to Americanization was to promote literacy, acquisition of English, and preparation for legal naturalisation..$^{\circ}$

Jones's scholarship is suggestive of a slant towards a culturally pluralistic perspective in the early progressive public library movement. Indeed, Kaufman notes that '[al]though Guerrier's programs fell far short of genuine multiculturalism, she did 
accept such "immigrant gifts" as folk dancing and had at least one of her plays translated so it could be performed in Italian'. ${ }^{\text {9I }}$ More, both Guerrier's memoir and the SEG News are devoid of acquiescence to Nativist ideology or Americanization. On the contrary, the SEG News content supports retention of native languages; promotes celebration of differing traditions, creeds, and beliefs; and reveals a cohort acutely cognizant of the pressures of Americanization exerted upon them-and at times this was acknowledged sardonically at the expense of the dominant culture, as for example in this tidbit from I9I3:

AMERICAN STUPIDITY OR SIMPLIFIED SPELLING? WHICH?

In Italy they called her

'Caterina Palma Giudice'

In Boston the teacher spells it

'Katherine Palmy George'92

When one views the SEG through the lens of Milton Park's seven-phase assimilation theory, one can ascribe the cohort's successes to the achievement of structural assimilation. This integration by the immigrant into the institutions of the dominant culture is conceptualised as the most comprehensive form of assimilation. It then seems reasonable to postulate that participation in the SEG correlated to an assimilation outcome in keeping with Kallen's principles of cultural pluralism, in which the features of the immigrant culture are actively contributed to the entire community, thereby creating a stronger, cohesive whole.

And yet when one reflects upon Guerrier's initial inception of the reading clubs, one finds little to suggest that her focus was on acculturation in the foundational sense. She expresses instead a hope that her charges become independent, critical thinkers. Guerrier paraphrased her 1899 introduction to the story hour thus:

Some day you girls are going to enter the business world. You will need to know how to use the tool called mind, so that you can do your own thinking. You will need to know how to cooperate, and how to give and take with good-humored self-control. You will need to have a well-informed mind, and if you are to win positions with people you can respect and admire, you will need to have a sense of the values of good literature, good music, and good recreation..$^{93}$

It might be most useful to view Guerrier's conscious intent as one which focused less on acculturation and more on the cultivation of personal agency within the clubs' individual members.

Bandura defines agency as 'the human capacity to exert influence over one's functioning and the course of events by one's actions'. He further postulates the 'properties' of agency as intentionality, forethought, self-regulation, and self-reflection, all of which may be seen in personal, proxy, or collective forms. ${ }^{94}$ Throughout her narrative and the historical record, Guerrier envisions the SEG members as those who are able to think and learn independently, to plan for the future, to modulate themselves productively, and to both advocate for and create change in the world. And the SEG News is replete with examples of young women whose sense of self and position in the world is entirely consonant with the concept of agency in its personal, proxy, and collective forms-chief among them, the SEG News editor Fannie Goldstein.

From as early as I9I3, Miss Goldstein was quite clear in her conviction that: 
To be an S. E. G. is a privilege. It has (you will agree with me) meant an 'Open Sesame' both mentally and materially to a great many of the girls who are today members of the group [...] Now we are no longer children. We are a group of responsible young women, alert and ever ready for an opportunity. ${ }^{95}$

Goldstein's contributions throughout the serial, both in the selection of content and in her own editorials and articles, demonstrate a self-aware thoughtfulness, an abundance of intellectual curiosity, and ample capacity to tolerate dialectical points of view.

For example, on at least three occasions, Goldstein used her editorial platform to rebuke social welfare agents. ${ }^{96}$ In one such article, she pointedly admonished those social case workers who sought to 'push' change according to their world view onto an individual rather than to 'pull' change from an individual as an organic by-product of their innate potential. ${ }^{97}$ Simultaneously, Goldstein published the work of her SEG colleague Rebecca Heiman, who wrote favourably about local settlement entities such as Denison House, ${ }^{98}$ Lincoln House, ${ }^{99}$ and the Hull Street Settlement. ${ }^{\text {Ioo }}$

\section{Guerrier as a 'new woman': promotion of agency versus proxy for social control}

All in all, Guerrier's resumé is impressive, one of an exemplary 'new woman'. And yet the more one examines Guerrier with regard to her perceived experience as a 'new woman', the more elusive she becomes. Her memoir is reticent in revealing substantive insights into her personal or inner life, ${ }^{\text {IOI }}$ and, with the exception of the moving narrative of her early childhood, reviewers of her autobiography note an guarded overall style. $^{\text {ro2 }}$

If details of her personal life remain veiled and her convictions largely inferential, one facet of Guerrier's inner life that the archival record does illuminate is her desire to produce children's literature. And herein one can observe another example of the dichotomy between promotion of a progressive social agenda and adherence to Victorian morality. The SEG News published at least eight children's plays written by Guerrier, some original and some retellings of classics. A book of animal fables written by Guerrier and illustrated by Brown, entitled Wanderfolk in Wonderland, was published by Small, Maynard \& Co. in 1903. ${ }^{103}$ But her initial I902 attempt to publish the animal tales met with rejection, as did subsequent works including dramatisations of Anderson and Hawthorne fables (I908) and a drama entitled The Social Workers (I9I3).

The readers at Houghton Mifflin found her submissions unexceptional: 'All show considerable play and fancy and some skill in construction, but the humor and imagination is not very well sustained'; ${ }^{\text {IO } 4}$ 'almost any intelligent person with the stories in hand could have done as well'; '105 'a drama with much talk and little action'; 'It's not very readable and I can't see any life for it.' ${ }^{\text {IO6 }}$ More important, the content of Guerrier's stories and plays is at times perplexing. The plays can take a pejorative tone with strong subtext as to what were and were not appropriate behaviour and attitudes among both social welfare workers and immigrants alike. For example, in a play titled The Board of Health, Guerrier dramatises the function of the board in remediating poor plumbing, fire hazards, and contagion of virulent 
illnesses within the urban immigrant community. She names the 'friendly visitor' Miss Bendorbreak, whose exaggerated manner bespeaks exasperation with the Italian immigrant family in her charge. Meanwhile, the portrayal of the family is replete with eyebrow-raising stereotypes, including the use of phonetically spelled, heavily accented pidgin English. ${ }^{\text {IO7 }}$

If reading The Board of Health in isolation, one might conclude that Guerrier chose to caricature all the players equally in their worst light as objects of humour. Yet when it is read alongside her other works a decidedly conservative picture emerges, with her fables and stories all primarily appearing as morality tales infused with familiar, traditional Victorian mores. While Guerrier's aspirations for the SEG may have focused on the girls' agency, her writing indulges stereotypes of immigrant communities and familiar themes of social control associated with the efforts of those who promoted Americanization. In her examination of the survey records created by Progressive Era youth librarians, McDowell notes similarly that the librarians' observations, goals, and interventions at times reiterate the stereotypes and prejudices broadly held by the Victorian middle and upper classes with regard to immigrants. ${ }^{\text {1०8 }}$

The assertion of Abrams and Garrison that the 'new woman' did not reject conventional values outright but rather redirected them from home to community may be provocative. Yet it also may prove useful when considering the seeming contradiction between Guerrier's commitment to SEG readers as young women with ample capacity for self-direction and the conservative, socially controlling elements we detect in her creative writing. Guerrier and other 'new women' were, after all, products of their times. And thus perhaps there is a dialectical truth that 'new women' at times demonstrated an internalisation of the same mores that drove the institutions they sought to change.

But there is one further element to Guerrier's story that complicates this reading still further, which is her deep, empathetic connection with and lifelong devotion to the SEG membership and, perhaps more tellingly, the fervent reciprocity of these sentiments. Of this, the historical record is amply indicative, especially when one considers the two-inch-thick, leather-bound volume embossed in gilt letters 'Friendship Letters to EDITH GUERRIER from the S.E.G., Sept. 20, I950', ${ }^{\text {IO9 }}$ filled and overflowing with heartfelt tributes from SEG members who were then in their middle age, or perhaps the words of Annie Adelson, who in 1953 prayed on behalf of herself and her daughters 'that all three of us may so live that you will always be proud of us as we are proud of and blessed by your friendship'. ${ }^{\text {Iо }}$

In the end, one suspects that Guerrier herself would abjure attempts at contextualisation or analysis of her contributions beyond that of 'friend'. It may be Guerrier's own words that most simply and eloquently express the essence of the SEG:

About fifty years ago our Story Hour started. Since that Spring day long ago we have acquired many new members, and many of our loved friends are no longer with us. Those of us who are still here have happy memories of Club House, Camp and Library, but the outstanding memory is of our precious friendship and what those friendships have meant to us. Nothing in the world can take the place of true friendship. The happy smile, the kind word, the reassuring hand-clasp of a friend offer cheer and courage which nothing else can give. ${ }^{\text {III }}$ 


\section{Notes}

I D. M. Barbuto, 'Introduction,' in American Settlement Houses and Progressive Social Reform: An Encyclopedia of the American Settlement House Movement, ed. by Domenica M. Barbuto (Phoenix, AZ: Oryx Press, I999), pp. vii-ix; J. D. Buenker, 'The Gilded Age and Progressive Era: I877-1919', in Encyclopedia of the Gilded Age and the Progressive Era, ed. by John D. Buenker and Joseph Buenker (Armonk, NY: Sharpe Reference, 2005), pp. I-I3.

2 Buenker, pp. I-I3.

3 N. I. Painter, 'The Depression of the I89o's,' in Standing at Armageddon: A Grassroots History of the Progressive Era (New York: W. W. Norton \& Company, Inc., I987), pp. IIo-I40.

4 Buenker, pp. I-I3.

5 V. Greene, 'Immigration and Ethnicity,' in Encyclopedia of the Gilded Age and Progressive Era, ed. by Buenker and Buenker, pp. 44-50.

6 E. Havens, 'The Ventriloquist Who Changed the World,' American Libraries, 38.7 (2007), 54-57.

7 W. A. Wiegand, The Politics of an Emerging Profession (Westport, CT: Greenwood Press, 1986).

8 A. McCrossen, “"One Cathedral More” or "Mere Lounging Places for Bummers"? The Cultural Politics of Leisure and the Public Library in Gilded Age America,' Libraries \& Culture, 4I.2 (2006), I69I88.

9 R. R. Du Mont, 'The Library and Social Reform,' in Reform and Reaction: The Big City Public Library in American Life (Westport, CT: Greenwood Press, I977), pp. 3I-49.

Io D. Garrison, Apostles of Culture: The Public Librarian and American Society, I876-I920 (Madison, WI: University of Wisconsin Press, 2003).

II Ibid.

I2 S. M. Evans, 'Women and Modernity, I890-I920,' in Born for Liberty: A History of Women in America (New York: The Free Press, I986), pp. I45-73.

I3 Garrison.

${ }^{I}$ M. N. Maack, 'Gender, Culture, and the Transformation of American Librarianship, I890-I920,' in The History of Reading and Libraries in the United States and Russia (= Libraries \& Culture, 33.I (I998)), 5I-6I.

I5 S. Pimpare, 'Charity Organization Societies,' in Encyclopedia of the Gilded Age and Progressive Era, ed. by Buenker and Buenker, p. 293.

W. I. Trattner, From Poor Law to Welfare State: A History of Social Welfare in America, 6th edn (New York: The Free Press, 1999).

I6 Painter; Buenker, pp. I-I3.

17 Trattner.

I8 Ibid.
I9 R. C. Reinders, 'Toynbee Hall and the American Settlement Movement,' Social Service Review, 56.I (I982), 39-54.

20 Painter; Buenker, pp. I-I3.

2 I Barbuto; Trattner.

22 Trattner.

23 J. McDonough, 'Women Reformers in the Progressive Era,' Social Education, 63.5 (I999), 3I 5-3I9.

24 E. Guerrier, An Independent Woman: The Autobiography of Edith Guerrier, ed. by Molly Matson (Amherst, MA: University of Massachusetts Press, I992), p. I2.

25 M. Matson, Preface and Introduction to Guerrier, An Independent Woman, pp. xviv-xxxix.

26 K. C. Larson, 'The Saturday Evening Girls: A Progressive Era Library Club and the Intellectual Life of Working Class and Immigrant Girls in Turn-ofthe-Century Boston,' Library Quarterly, 71.2 (200I), I95-230.

27 Matson, Preface and Introduction; Guerrier.

28 P. W. Kaufman, Foreword to Guerrier, An Independent Woman, pp. xi-xviii; Larson.

29 Larson; Guerrier.

30 Guerrier; Larson.

3 Larson; Matson, Preface and Introduction; Guerrier.

32 Larson.

33 Ibid.

34 Kaufman.

35 Larson; N. Gadsden, Art and Reform: Sarah Galner, the Saturday Evening Girls, and the Paul Revere Pottery (Boston, MA: Museum of Arts Publishing, 2006).

36 Matson, Preface and Introduction; Guerrier.

37 Larson.

38 Ibid.; Gadsden.

39 Gadsden; Larson.

$4^{\circ}$ Gadsden; Guerrier.

4I M. Chalmers and J. Young, The Saturday Evening Girls: Paul Revere Pottery (Atglen, PA: Schiffer Press, 2005);Gadsden.

42 Gadsden; Chalmers and Young.

43 Guerrier; Larson.

44 K. McDowell, 'Toward a History of Children as Readers, I890-I930,' Book History, I2 (2009), 240-65.

45 Ibid.

46 C. M. Hewins, Books for Boys and Girls, 3rd edn, rev. (Chicago: American Library Association Publishing Board, I9I5).

47 E. M. Richardson, 'Good Books and Bad', Saturday Evening Girls News (SEG News), 4.4 (I2 February 19I6). The newsletter is available in a print volume at the Boston Athenaeum.

$4^{8}$ SEG News, 3.6 (Io April I9I5). 
49 Kaufman; Larson.

50 Gadsden; Chalmers and Young.

5 I Evans.

52 Larson; L. S. Abrams and L. Curran, 'Wayward Girls and Virtuous Women: Social Workers and Female Juvenile Delinquency in the Progressive Era,' Affilia: Journal of Women \& Social Work, I 5. I (2000), 49-64.

53 Abrams and Curran, 'Wayward Girls and Virtuous Women.'

54 B. W. Lukenbill, 'Helping Youth at Risk: An Overview of Reformist Movements in American Public Library Services to Youth', New Review of Children's Literature and Librarianship, I2.2 (2006), I97-2I3.

55 J. B. Pierce, "Why Girls Go Wrong”: Advising Female Teen Readers in the Early Twentieth Century,' Library Quarterly, 77.3 (2007), 3I I-326.

56 Ibid.

57 E. Hamilton-Honey, 'Guardians of Morality: Librarians and American Girls' Series Fiction, I890-I950,' Library Trends, 60.4 (20I2), 765-785.

$5^{8}$ Guerrier.

59 Hamilton-Honey.

60 L. S. Abrams, 'Guardians of Virtue: The Social Reformers and the "Girl Problem", I890-I920', Social Service Review, 74.3 (2000), 436-52.

6I Abrams and Curran, 'Wayward Girls and Virtuous Women.'

62 A. C. Kennedy, 'Eugenics, "Degenerate Girls", and Social Workers during the Progressive Era,' Affilia: Journal of Women \& Social Work, 23.I (2008), 22-37; S. Marshall, 'Social Hygiene,' in Encyclopedia of the Gilded Age and Progressive Era, ed. by Buenker and Buenker.

63 Kennedy, 'Social Hygiene.'

64 Ibid.; Abrams and Curran, 'Wayward Girls and Virtuous Women.'

65 Abrams.

66 L. S. Abrams and L. Curran, 'Between Women: Gender and Social Work in Historical Perspective,' Social Service Review, 78.3 (2004), 429-446.

67 Kennedy, 'Social Hygiene.'

68 Garrison; Pierce.

69 S. Hildenbrand, 'Revision Versus Reality: Women in the History of the Public Library Movement,' in The Status of Women in Librarianship, ed. by Kathleen M. Heim (New York: Neal-Shuman Publishers, I983), pp. 7-27.

70 J. Valentine, 'Our Community, Our Library: Women, Schools, and Popular Culture in the Public Library Movement,' Public Library Quarterly, 24.4 (2005), 45-79.

$7 \mathrm{I}$ C. Pawley, 'Foreword: Reading Apostles of Culture: The Politics and Historiography of Library History,' in Garrison, pp. xvii-xxxiv.

72 Larson; Matson, Preface and Introduction.
73 Ibid.

74 M. Paul, 'Assimilation,' in Encyclopedia of Race, Ethnicity, and Society, ed. by R. T. Schaefer (Thousand Oaks, CA: SAGE Publications, 2008), I, pp. IO4-IO7.

75 L. Q. Wang, 'Assimilation Theories,' in Encyclopedia of American Immigration, ed. by C. L. Bankston III (Pasadena, CA: Salem Press, 20Io), I, pp. $84-86$.

76 H. C. Lee, 'Assimilation Theory,' in Race and Racism in the United States: An Encyclopedia of the American Mosaic, I, ed. by C. A. Gallagher and C. D. Lippard (Santa Barbara, CA: Greenwood, 20I4), I, pp. 82-84.

77 Ibid.

78 Paul.

79 Lee, 'Assimilation Theory.'

80 Wang.

8I Paul.

82 E. M. Mazur, 'Americanization,' in Encyclopedia of Race, Ethnicity, and Society, ed. by Schaefer, I, pp. 62-64.

83 E. Vesselinov, 'Americanization,' in Encyclopedia of Social Problems, ed. by V. N. Parrillo (Thousand Oaks, CA: SAGE Publications, 2008), pp. 4445 .

${ }^{84}$ G. Meyer, 'The Cultural Pluralist Response to Americanization: Horace Kallen, Randolph Bourne, Louis Adamic, and Leonard Covello,' Socialism and Democracy, 22.3 (2008) <http://sdon line.org/48/the-cultural-pluralist-response-to-ameri canization-horace-kallen-randolph-bourne-louisadamic-and-leonard-covello/> [accessed 7 July 20I6].

85 Ibid.; M. Haas, 'Cultural Pluralism,' in Encyclopedia of American Immigration, ed. by Bankston, I, pp. $265-267$. Haas, 'Cultural Pluralism.'

87 Meyer.

88 P. A. Jones Jr, 'Introduction' and 'Libraries, Immigrants, and Free Immigration, I876-I924,' in Libraries, Immigrants, and the American Experience (Westport, CT: Greenwood Press, I999), pp. I-37.

89 Ibid.; Meyer.

90 Jones.

9I Kaufman.

92 SEG News, 2.2 (I3 December I9I3).

93 Guerrier, p. 79

94 A. Bandura, 'Agency,' in Encyclopedia of the Life Course and Human Development, II: Adulthood, ed. by Deborah Carr (Detroit: Macmillan Reference USA, 2006), pp. 8-II.

95 F. Goldstein, in SEG News, 2.I (8 November I9I3).

96 F. Goldstein, in SEG News, 2.4 (I4 February I9I4); 3:6 (Io April I9I5); 4.4 (I2 February I9I6).

97 F. Goldstein, in SEG News, 2.4 (I4 February I9I4). 
98 R. Heiman, 'Denison House,' SEG News, 3.I (I4 November I9I4).

99 R. Heiman, 'Lincoln House,' SEG News, 3.3 (January 1915$)$.

Ioo R. Heiman, 'Denison House,' SEG News, 4.2 (December I9I5).

IoI Matson, Preface and Introduction.

IO2 S. Hildenbrand, 'Review: An Independent Woman: The Autobiography of Edith Guerrier, Edited by Molly Matson,' Library Quarterly, 63.I (1993), I26-I27; J. Passet, 'Review: An Independent Woman: The Autobiography of Edith Guerrier, ed. by Molly Matson,' Libraries \& Culture, 29.2 (I994), 24I.

I03 E. Guerrier, Wanderfolk in Wonderland: A Book of Animal Fable Stories (Boston: Small, Maynard \& Co., I903).

I04 Houghton Mifflin Company reader reports on manuscripts submitted for publication, I882-I93I, Houghton Library at Harvard College, MS Am 2516, bMS Am 2516 (9555)-(9999), box 26, item 9902, I902.
IO5 Ibid., bMS Am $25 \mathrm{I} 6$ (A385I)-(A4190), box 38, item $\mathrm{A}_{4} \mathrm{I} 45$, 1908 .

I06 Ibid., bMS Am 25I6 (A882I)-(A9210), box 5I, item A904I, I9I3.

107 E. Guerrier, The Board of Health, The Schlesinger Library, Radcliffe Institute, Harvard University, The Saturday Evening Girls Records, I9I0-I99I, Acc. No.: 200I-m50, box I, folder 5 .

I08 K. McDowell, 'Children's Voices in Librarians' Words, I890-1930,' Libraries and the Cultural Record, 46.I (20II), 73-IOI.

I09 New Bedford Whaling Museum Research Library, Mss I3: The Ricketson Family Papers, Sub-Group I2: Edith Guerrier Papers, $c$. I89I-I958, Series A: Correspondence, c. I89I-I957, sub-series I: Incoming, I900-I957, box 7 , vol. I.

IIO Ibid., box 7, folder 6 .

III E. Guerrier, 'The SEG Pin', April I954, The Schlesinger Library, The Saturday Evening Girls Records, I9I0-I99I, box I, folder 5 .

\section{Notes on contributor}

Margaret Bausman, LCSW-R, MSLIS, is an Assistant Professor on the faculty of the Hunter College Libraries, where she serves as the Head of the Social Work and Public Health Library. She earned an MSc in Library and Information Science degree from Long Island University's Palmer School in 20I0. Prior to this, Ms Bausman worked as a clinical and administrative social worker in children's mental health services, having completed a master's degree in social work at New York University in I995. Ms Bausman's research interests include the development of the helping professions during the Progressive Era with particular focus on the intertwined evolution of librarianship and social work, the construct of the new woman, and the social justice movements of the time.

Correspondence to: Margaret Bausman. Email: mbausman@hunter.cuny.edu

The research for this paper was supported by an award from the Professional Staff Congress-City University of New York in order to fund travel to and study in the Schlesinger Library/Radcliffe Institute and Houghton Library at Harvard University, the Harvard University Archives, the Boston Athenaeum, the Concord Free Library, and the New Bedford Whaling Museum Research Library. 
Copyright of Library \& Information History is the property of Taylor \& Francis Ltd and its content may not be copied or emailed to multiple sites or posted to a listserv without the copyright holder's express written permission. However, users may print, download, or email articles for individual use. 